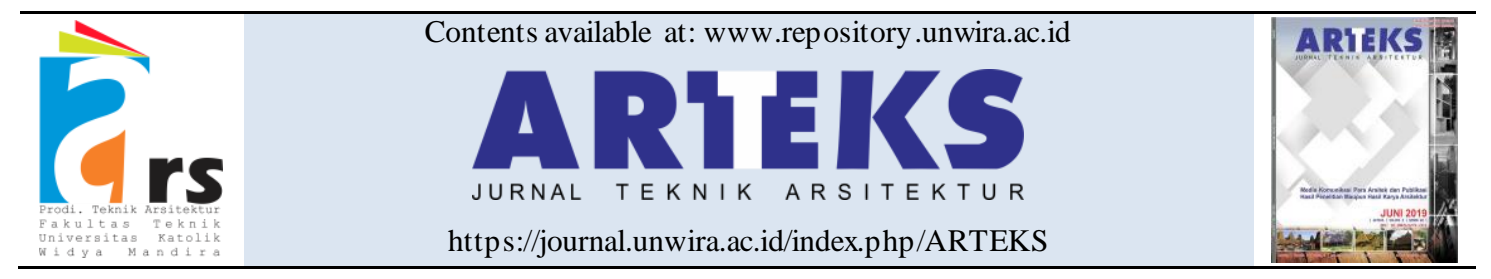

Research paper

doi: 10.30822/arteks.v6i1.641

\title{
The effect of adding rice husk ash and coconut fiber on the compressive strength of white bricks
}

\author{
Kristiana Bebhe*, Richardus Daton \\ Architecture Study Program, Faculty of Engineering, Universitas Katolik Widya Mandira, \\ Jl. San Juan, East Penfui, Kupang - East Nusa Tenggara, Indonesia
}

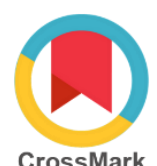

\begin{tabular}{|c|c|}
\hline ARTICLE INFO & ABSTRACT \\
\hline $\begin{array}{l}\text { Article history: } \\
\text { Received July } 25,2020 \\
\text { Received in revised form August } 12 \text {, } \\
2020 \\
\text { Accepted October } 11,2020 \\
\text { Available online April } 01,2021 \\
\end{array}$ & $\begin{array}{l}\text { White soil is a common material in Timor Island, especially in } \\
\text { Kupang, usually molded into bricks without adding sand due to its } \\
\text { high sand content which has been recorded to be between } 30-65 \% \text {. } \\
\text { This study was, therefore, conducted to determine the effect of } \\
\text { adding husk ash and coconut fiber on the compressive strength of } \\
\text { white soil bricks mixture using an experimental method. The process }\end{array}$ \\
\hline $\begin{array}{l}\text { *Corresponding author: Kristiana Bebhe } \\
\text { Architecture Study Program, } \\
\text { Faculty of Engineering, Universitas Katolik } \\
\text { Widya Mandira, Indonesia } \\
\text { Email: kristianabebhe@yahoo.com }\end{array}$ & $\begin{array}{l}\text { involved drying the white soil bricks using winding for } 28 \text { days after } \\
\text { molding after which the compressive strengths for the coconut fiber } \\
\text { with cement and rice husk with cement were measured. The results } \\
\text { showed a ratio of } 1 \text { coconut fiber to } 1 \text { cement produced } 7 \text { white soil } \\
\text { with compressive strength at } 147 \mathrm{~kg} / \mathrm{cm}^{2} \text { while } 1.5 \text { rice husk ash to } 1 \\
\text { cement produced } 7 \text { white soil with } 114.3 \mathrm{~kg} / \mathrm{cm}^{2} \text {. These were, } \\
\text { however, observed to be much higher than the findings of previous } \\
\text { studies which used } 1 \text { cement to } 7 \text { white soil to produce } 51.9 \mathrm{~kg} / \mathrm{cm}^{2} \text {. } \\
\text { This, therefore, means the compressive strength produced in this } \\
\text { study exceeds the value for quality } 1 \text { bricks based on SNI 03-0349- } \\
1989 \text { for loaded and unprotected constructions. }\end{array}$ \\
\hline
\end{tabular}

\section{Introduction}

Kupang Regency in East Nusa Tenggara Province has calcareous soil which is known as the "white soil" in natives' local language. It is used by the community for filling and also as additional material to make concrete bricks. Meanwhile, rice husks and coconut husks are waste materials easily found in rice mills and coconut peeling places respectively.

Rice husks have hygroscopic properties, low specific gravity, reported to be insulating materials (Coniwanti, Srikndhy, and Apriliyanni 2008) and are currently being developed as raw materials for RHA (rice husk ask) (Abdian and Herbudiman 2010) which contains very high pozzolan and has the ability to save the quantity of cement to be used in constructions (Is mail and Waliuddin 1996).
Coconut fiber is also durable, resilient, has strong against friction and fracture, waterresistant, and is non-biodegradable (Elhusna and Suwandi 2012). It is used in making white soil bricks due to its ability to reduce cracking (Mulyono 2004) but decomposable by a decomposer (Arman 2016).

This research experimented variants of white soil bricks added with rice husk ash and coconut fiber based on the hypothesis that the mixtures have high compressive strengths which meet SNI 03-0349-1989 and a lightweight which are applicable in different types of construction. This hypothesis is based on the problem formulation which is "is there an effect of rice husk ash or coconut fiber additions on the weight and compressive strength of white soil?"

The purpose of this study was, therefore, (1) to determine the effect of adding rice husk ash and 
coconut fiber to the compressive strength and bricks weight and (2) to determine the compliance of the white soil bricks compressive strength with the SNI 03-0349-1989 standard and its usability in building construction. The findings are expected to be a reference for the community, contractors, and architects as well as students to utilize the wealth of white land, rice husk waste, and coconut coir as building wall materials.

\section{Method}

The research was conducted in Kupang in collaboration with the Material Testing Laboratory, Ministry of Public Works, East Nusa Tenggara Province. The materials studied were white soil, rice husk ash, and coconut fiber as well as experimental bricks made from these materials.

The stages and procedures used in this research are as shown in diagram 1 and it contains researching brick-forming materials and experiments using 4 variants as indicated in table 4.

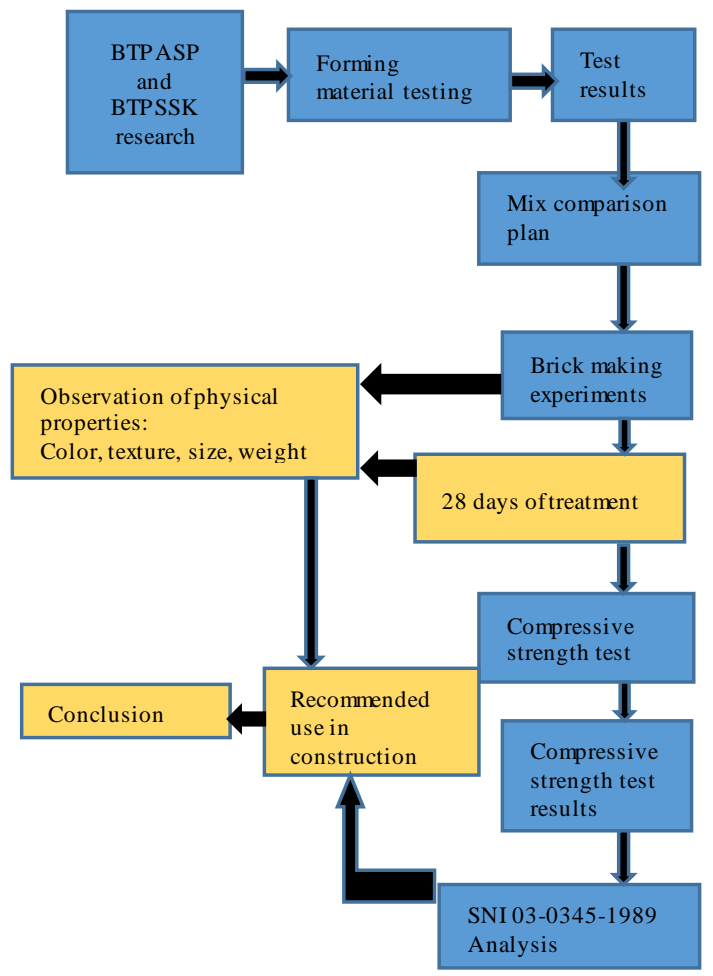

Description:

BTPASP is white soil brick with ash from rice husk

BTPSSK is a white soil brick with coconut fiber

Digram 1. Schematic of the research prosedure
The research on white soil bricks, rice husk ash, and coconut fiber was initiated by examining the forming materials from literature studies after which the mix comparisons were planned and brick-making experiments conducted. The brick was physically observed and aerated for 28 days before it was weighed and tested for its compressive strength as shown in figure 1 . The results and the weight measured was recorded to analyze the weight strength quality in line with SNI 03-0345-1989 and the recommendations for its use in construction according to the required compressive strength.
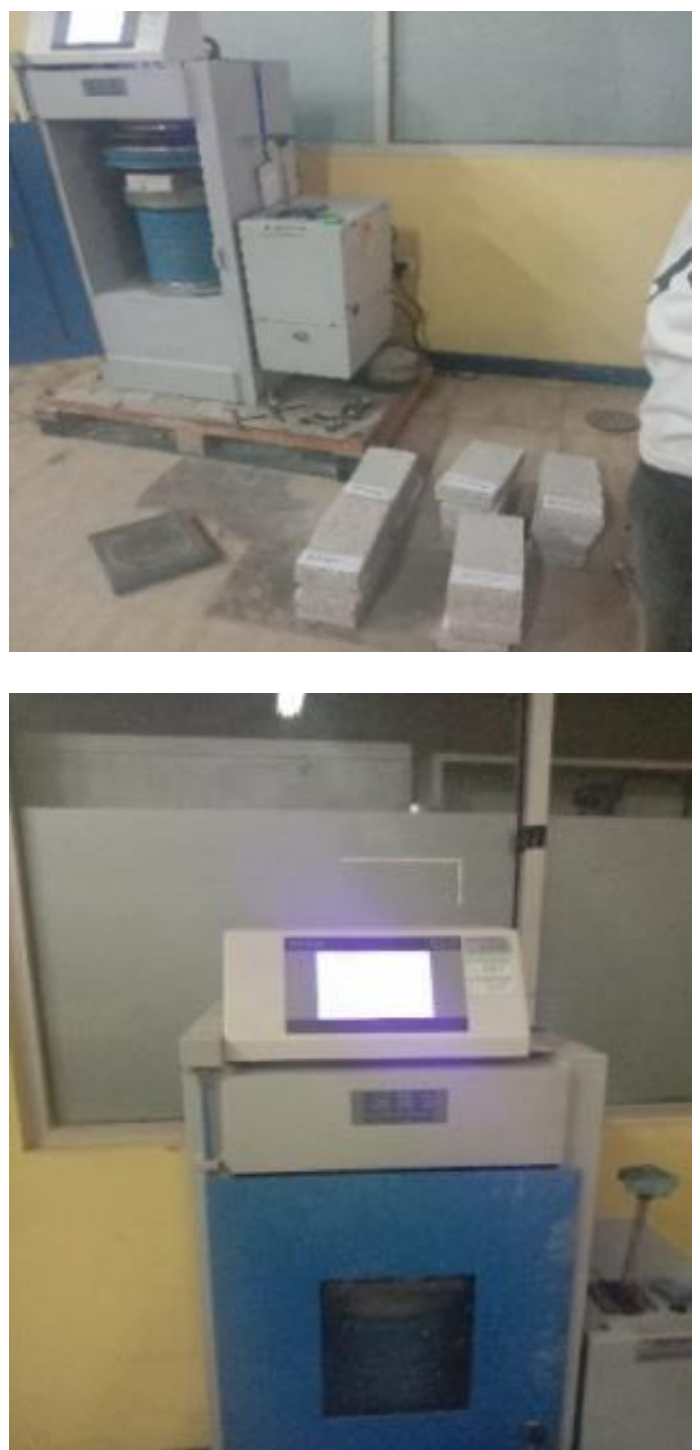

Figure 1. The $200 \mathrm{kN}$ digital compression machine test device at Material Testing Laboratory, Ministry of Public Works, East Nusa Tenggara Province 
The comparis on of the mixture of white soil bricks, Portland cement, rice husk ash, and coconut fiber are shown in table 1 :

Table 1. Comparison of the mixture of white soil research materials, Portland cement, husk ash, and coconut fiber

\begin{tabular}{llllll}
\hline B RICK & PC & TP & ASP & SSK & Total \\
\hline BTPASP1 & 1 & 7 & 1 & - & 5 \\
\hline BTPASP2 & 1 & 7 & 1,5 & - & 5 \\
\hline BTPSSK1 & 1 & 7 & - & 1 & 5 \\
\hline BTPSSK2 & 1 & 7 & - & 1,5 & 5 \\
\hline
\end{tabular}

Description:

$\mathrm{TP}=$ White soil, $\mathrm{PC}=$ Portland cement, $\mathrm{SSK}=$ Coconut fiber, $\mathrm{ASP}=$ rice husk ash, $\mathrm{BTPASP}=$ white soil brick with rice husk ash, and BTPSSK = white soil brick with coconut fiber. The mixtures were compared using 4 variants including (1) 1 cement: 7 white soil: 1 rice husk ash, (2) 1 cement: 7 white soil: 1.5 rice husk ash, (3) 1 cement: 7 white soil: 1 coconut fiber, and (4) 1 cement: 7 white soil: 1.5 coconut fiber.

\section{Material preparation}

The white soil was sieved with a $3 \mathrm{~mm}$ diameter sieve with the particle produced presented in figure 2 while the rice husks were burned manually to become gray and sieved using a flour sieve with the product shown in figure 3 . Moreover, the coconut coir was shredded and cleaned to become $15-20 \mathrm{~cm}$ fibers as indicated in figure 4 and the Kupang cement type 2 was also prepared as shown in figure 4.

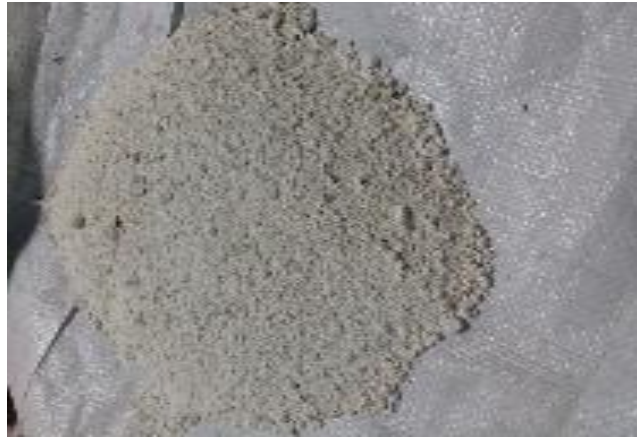

Figure 2. White soil after sieving

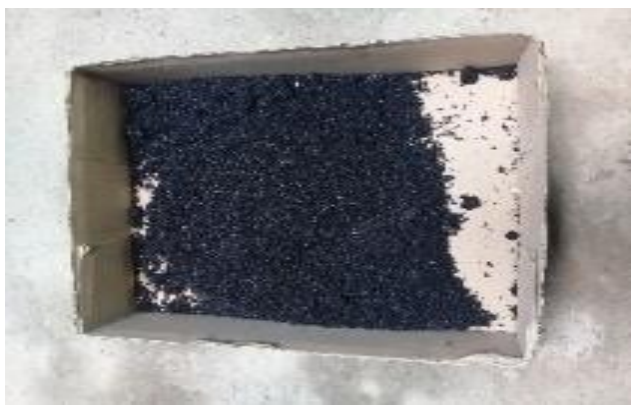

Figure 3. Burned rice husk ash

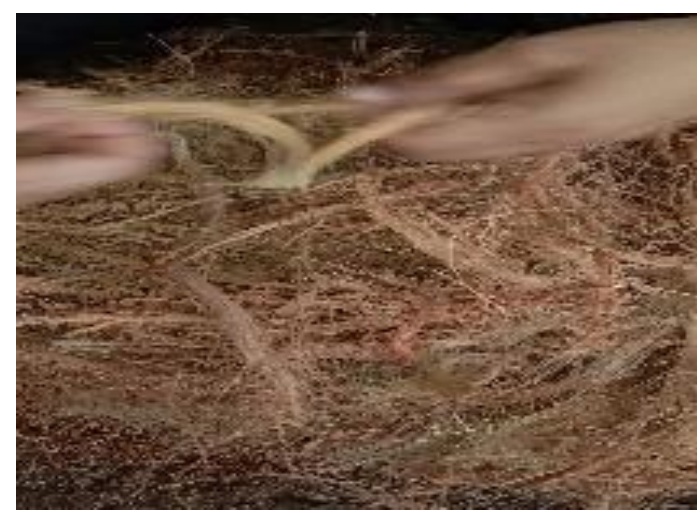

Figure 4. The coconut coir is shredded and cleaned until it becomes fine fibers

Compressive strength test formula

Compressive strength $=\mathrm{F} / \mathrm{A}$

Where:

$\mathrm{F}=$ crushed load $(\mathrm{kg})$;

$\mathrm{A}=$ Compression Area $\left(\mathrm{cm}^{2}\right)$

\section{Data collection techniques and analysis methods}

Data were collected by (1) recording the observations results and measurements of experimental bricks to analyze their quality and use in building construction, and (2) documentation of work process, physical form, and compressive strength testing process.

The experimental bricks quality was analyzed using the physical requirements of concrete bricks based on SNI 03-0349-1989 as shown in table 2.

Table 2. Phy sical requirements of concrete bricks

\begin{tabular}{lcc}
\hline No & Quality & $\begin{array}{r}\text { Requirements for compressive } \\
\text { strength }(\mathbf{k g} / \mathbf{c m} 2)\end{array}$ \\
\hline 1 & I & 90 \\
\hline 2 & II & 65 \\
\hline 3 & III & 35 \\
\hline 4 & IV & 21 \\
\hline
\end{tabular}

The bricks used in building construction were analyzed using the compressive strength requirements of concrete bricks and SNI 03-03491989 as indicated in table 3.

Table 3. Analy sis of brick use based on compressive strength requirements

\begin{tabular}{ll}
\hline Construction Type & $\begin{array}{l}\text { Minimal compressive } \\
\text { strength }\end{array}$ \\
\hline $\begin{array}{l}\text { Overburdened and } \\
\text { unprotected construction }\end{array}$ & $66,30 \mathrm{~kg} / \mathrm{cm}^{2}$ \\
\hline $\begin{array}{l}\text { Loaded and protected } \\
\text { const ruction }\end{array}$ & $45,90 \mathrm{~kg} / \mathrm{cm}^{2}$ \\
\hline
\end{tabular}




\begin{tabular}{ll}
\hline Construction Type & $\begin{array}{l}\text { Minimal compressive } \\
\text { strength }\end{array}$ \\
\hline $\begin{array}{l}\text { Unencumbered and } \\
\text { unprotected construction }\end{array}$ & $30,60 \mathrm{~kg} / \mathrm{cm}^{2}$ \\
\hline $\begin{array}{l}\text { Unencumbered and protected } \\
\text { construction }\end{array}$ & $17,34 \mathrm{~kg} / \mathrm{cm}^{2}$ \\
\hline
\end{tabular}

\section{Result and discussion}

\section{White soil test material}

The test was conducted at Material Testing Laboratory, Ministry of Public Works (PU), East Nusa Tenggara Province, and the results are presented in table 4.

Table 4. White soil testing data compared to red soil/clay tested

\begin{tabular}{|c|c|c|c|}
\hline No & Type of test & $\begin{array}{l}\text { White soil test } \\
\text { results }\end{array}$ & $\begin{array}{l}\text { Red soil test } \\
\text { results }\end{array}$ \\
\hline 1 & $\begin{array}{l}\text { Conservation } \\
\text { of grain form }\end{array}$ & Do not crack & Do not crack \\
\hline 3 & $\begin{array}{l}\text { Soil binding } \\
\text { time with } \\
\text { water }\end{array}$ & $3 \times 24$ hours &.- \\
\hline 4 & $\begin{array}{l}\text { Average } \\
\text { density }\end{array}$ & $2,626 \mathrm{gr} / \mathrm{cm}^{3}$ & $\begin{array}{l}2661 \\
\mathrm{gr} / \mathrm{cm}^{3}\end{array}$ \\
\hline 6 & $\begin{array}{l}\text { Grain stuck in } \\
\text { the sieve: } \\
>2,00 \mathrm{~cm} \\
2,00 \mathrm{~cm}- \\
0,850 \mathrm{~mm} \\
0,850- \\
0,425 \mathrm{~mm} \\
0,250- \\
0,150 \mathrm{~mm} \\
>0,075 \mathrm{~mm}\end{array}$ & $\begin{array}{l}5 \% \\
10 \% \\
1 \% \\
3,5 \% \\
3,0 \%\end{array}$ & $\begin{array}{l}0 \% \\
0 \% \\
1 \% \\
3,6 \% \\
3,6 \%\end{array}$ \\
\hline 7 & Sand content & $30-65 \%$ & $7,2 \%$ \\
\hline
\end{tabular}

Source: (Bebhe 2017)

\section{Brick making experiments}

The equipment used to manufacture white soil bricks in this study include (a) $3 \mathrm{~mm}$ diameter sand sieve for the white soil, (b) flour sieve for rice husk ashes, (c) weighing devices, measuring cups, shovels, and sticks for crushing chunks of white soil, and buckets, (d) a wooden mold with the ability to produce 7 bricks with a size of $5 \mathrm{~cm} \mathrm{x}$ $23 \mathrm{~cm} \times 11 \mathrm{~cm}$ as shown in figure 5 .

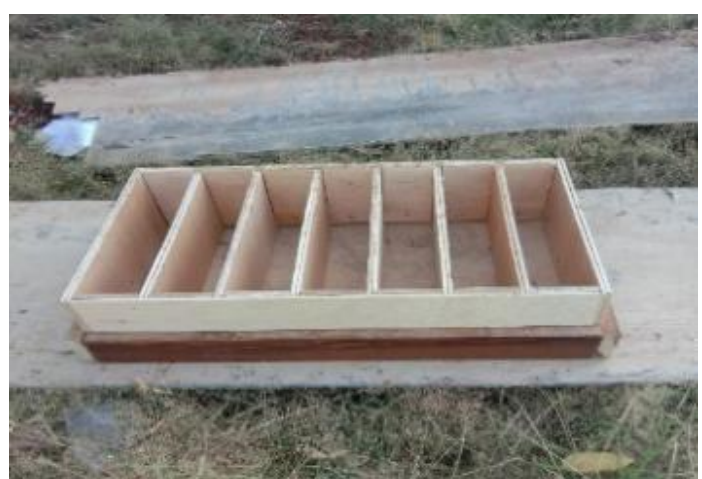

Figure 5. Molding tool

The brick molding steps include

a. BTPASP (white soil brick with rice husk ash) was produced by measuring white soil, rice husk ash, and cement according to plan as shown in figure 6 . All the materials were mixed evenly using a shovel and hands after which water was added and the combination mixed again to form a dough required for molding as shown in figure 7. Meanwhile, BTPSSK (white earth brick with coconut coir fiber) was produced by first mixing white soil material and cement with water as presented in figure 8 after which the coir fiber was filled into the new mold as indicated in figure 9.

b. The mold was placed on a flat floor after which the dough was poured and pressed to ensure the specimens have the same density. The mold was later lifted slowly to protect the brickwork from being damaged as shown in figure 10 .

c. The bricks were, therefore, placed on a flat and clean floor after molding at a distance 2$5 \mathrm{~cm}$ to each other and under a roofed room.

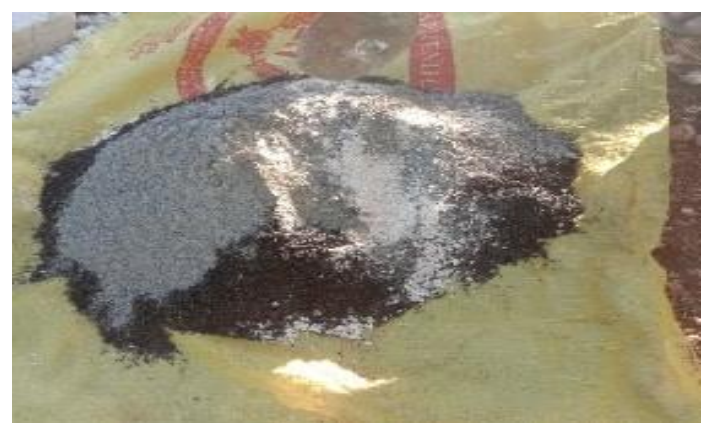

Figure 6. White soil + rice husk ash + cement, ready to be mixed 


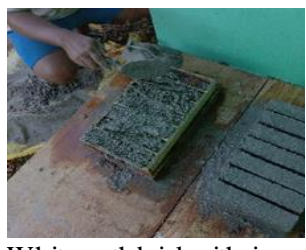

White earth brick with rice husk ash (BTPASP) 1

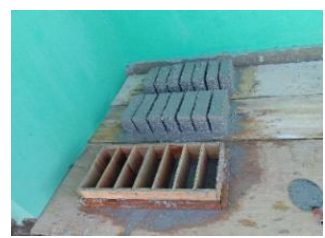

White earth brick with rice husk ash (BTPASP) 2
Figure 7. White soil bricks with rice husks (BTPASP 1 and 2) being molded and at the completion stage respectively

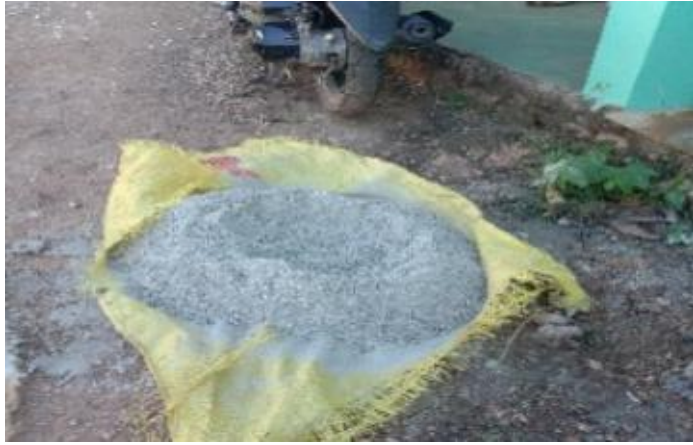

Figure 8. White soil + cement

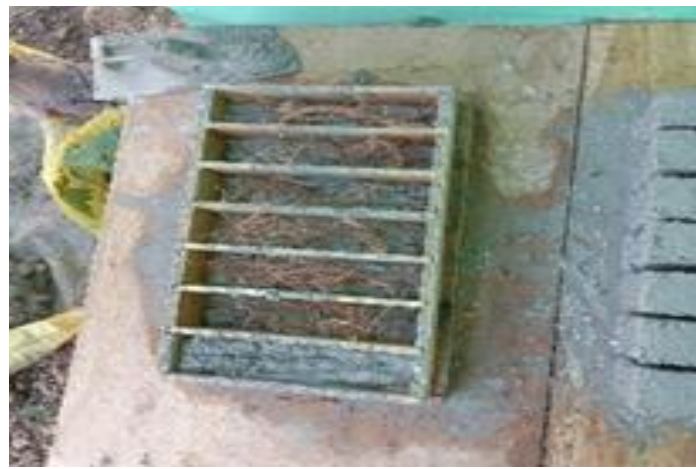

Figure 9. The brick dough was mixed with coconut fiber

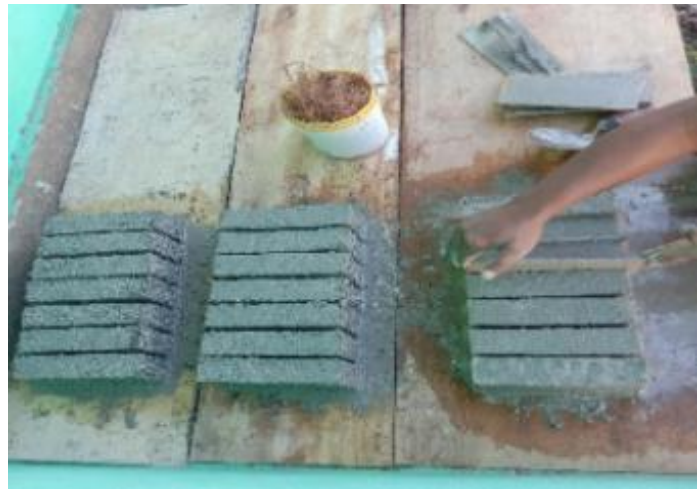

Figure 10. Molded coconut fiber bricks (BTPSSK 1 and 2)

\section{Physical form and compressive strength test of the bricks}

The shape, size, color, and physical properties of the bricks were tested and they were found to be rectangular with $11 \mathrm{~cm} \times 23 \mathrm{~cm} \times 5 \mathrm{~cm}$. The color is gray and the outer texture is smooth while the cracked texture on the inside is rough as shown in figure 11.

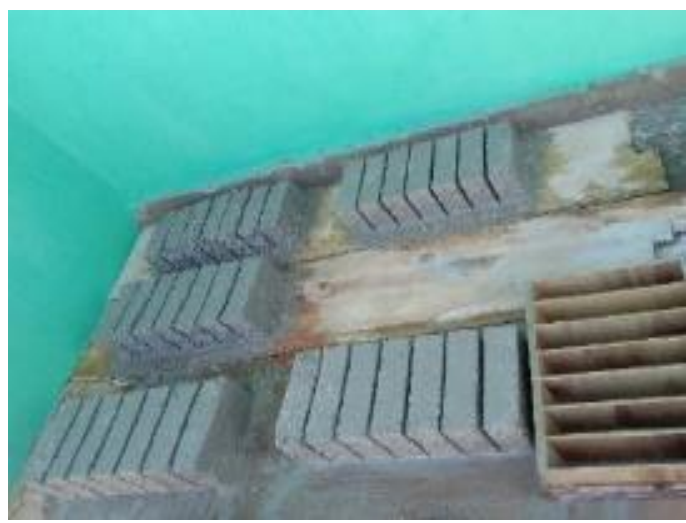

White soil brick with rice husk ash

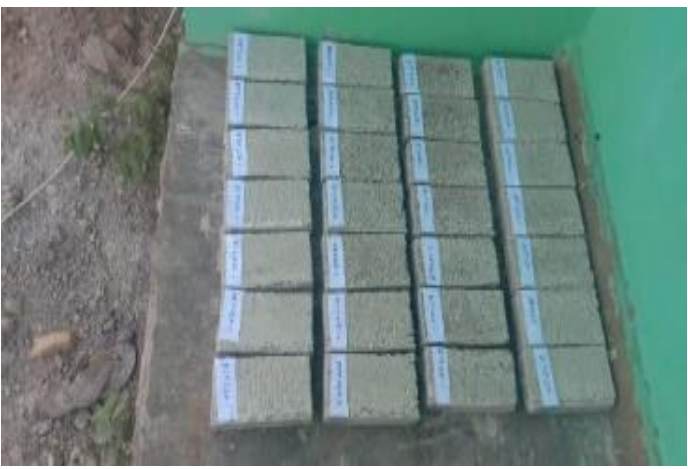

Coconut fiber brick

Figure 11. The newly molded and labeled white soil brick with rice husk ash (BTPASP) and coconut fiber brick (BTPSSK)

\section{Weight and compressive strength of the bricks}

The compressive strength was measured after 28 days and the results are presented in table 5 as follows.

Table 5. Measurement results for compressive strength

\begin{tabular}{ccccc}
\hline $\mathbf{N}$ & $\begin{array}{l}\text { Brick } \\
\text { code }\end{array}$ & $\begin{array}{c}\text { Weight } \\
(\text { gram })\end{array}$ & $\begin{array}{c}\text { Compressi } \\
\text { ve strength } \\
(\mathbf{k N})\end{array}$ & $\begin{array}{c}\text { Compressi } \\
\text { ve strength } \\
\left(\mathbf{k g} / \mathbf{c m}^{2}\right)\end{array}$ \\
\hline 1 & $\begin{array}{l}\text { BTPASP } \\
1\end{array}$ & 1929 & 143.9 & 57.5 \\
\hline 2 & $\begin{array}{l}\text { BTPASP } \\
1\end{array}$ & 1829 & 124 & 49,6 \\
\hline 3 & $\begin{array}{l}\text { BTPASP } \\
1\end{array}$ & 1759 & 143.2 & 57.2 \\
\hline
\end{tabular}




\begin{tabular}{clccc}
\hline $\begin{array}{l}\mathbf{N} \\
\mathbf{0}\end{array}$ & $\begin{array}{l}\text { Brick } \\
\text { code }\end{array}$ & $\begin{array}{l}\text { Weight } \\
(\text { gram })\end{array}$ & $\begin{array}{c}\text { Compressi } \\
\text { ve strength } \\
(\mathbf{k N})\end{array}$ & $\begin{array}{c}\text { Compressi } \\
\text { ve strength } \\
\left(\mathbf{k g} / \mathbf{c m}^{2}\right)\end{array}$ \\
\hline 4 & $\begin{array}{l}\text { BTPASP } \\
1\end{array}$ & 1760 & 135,4 & 54,1 \\
\hline 5 & $\begin{array}{l}\text { BTPASP } \\
1\end{array}$ & 1828 & 123.4 & 49,3 \\
\hline 6 & $\begin{array}{l}\text { BTPASP } \\
2\end{array}$ & 2037 & 213.1 & 85,2 \\
\hline 7 & $\begin{array}{l}\text { BTPASP } \\
2\end{array}$ & 2072 & 232.5 & 92.9 \\
\hline 8 & $\begin{array}{l}\text { BTPASP } \\
2\end{array}$ & 2014 & 229.2 & 91,6 \\
\hline 9 & $\begin{array}{l}\text { BTPASP } \\
2\end{array}$ & 2070 & 234 & 93,5 \\
\hline 10 & $\begin{array}{l}\text { BTPASP } \\
2\end{array}$ & 2117 & 286 & 114,3 \\
\hline 11 & $\begin{array}{l}\text { BTPSSK } \\
1\end{array}$ & 2286 & 302.9 & 121 \\
\hline 12 & $\begin{array}{l}\text { BTPSSK } \\
1\end{array}$ & 2251 & 349.3 & 139,6 \\
\hline 13 & $\begin{array}{l}\text { BTPSSK } \\
1\end{array}$ & 2240 & 367.8 & 147 \\
\hline 14 & $\begin{array}{l}\text { BTPSSK } \\
1\end{array}$ & 2251 & 338.4 & 135,2 \\
\hline 15 & $\begin{array}{l}\text { BTPSSK } \\
1\end{array}$ & 2255 & 349.3 & 139,6 \\
\hline 16 & $\begin{array}{l}\text { BTPSSK } \\
2\end{array}$ & 2254 & 225 & 89,9 \\
\hline 17 & $\begin{array}{l}\text { BTPSSK } \\
2\end{array}$ & 2172 & 274.5 & 109,7 \\
\hline 18 & $\begin{array}{l}\text { BTPSSK } \\
2\end{array}$ & 2138 & 211.6 & 84,6 \\
\hline 19 & $\begin{array}{l}\text { BTPSSK } \\
2\end{array}$ & 2254 & 225.3 & 90 \\
\hline 20 & $\begin{array}{l}\text { BTPSSK } \\
2\end{array}$ & 2213 & 264.6 & 105,7 \\
\hline & 225 & \\
\hline
\end{tabular}

The compressive strength and weight measured showed the following:

a. The highest compres sive strength for rice husk ash brick is $286 \mathrm{kN}$ or $114.3 \mathrm{~kg} / \mathrm{cm}^{2}$ (BTPASP2) and this was observed to be higher than the value for clay bricks only stabilized with white soil with the maximu m value recorded to be $38.69 \mathrm{~kg} / \mathrm{cm}^{2}$ (Bebhe 2018). Moreover, previous studies also reported rice husk ash brick to have compressive strength reaching 51.71MPA (Abdian and Herbudiman 2010) and $11.53 \mathrm{MPa}$ or $203.5 \mathrm{kN}$ while some were lower with $14.32 \mathrm{~kg} / \mathrm{cm}^{2}$ and $15.43 \mathrm{~kg} / \mathrm{cm}^{2}$ (Zulfikar 2014).

b. The brick mixed with coconut fiber (BTPS SK 1) was recorded to have the highest compressive strength of $367.8 \mathrm{kN}$ or 147 $\mathrm{kg} / \mathrm{cm}$ and this is higher than previous studies which added $0.3 \%$ fiber to produce $20.43 \mathrm{MPa}$ or $360.6 \mathrm{kN}$ (Budiman and Patanduk 2018), 244,84kN (Sahrudin and Nadia 2016), and
$33,566 \mathrm{MPa}$ or $610 \mathrm{kN}$ (Fandy, Anita, and Handoko 2013). This means coconut fibers have the ability to increase the compressive strength of bricks (Susilowati, Simanullang, and Aprilia 2016). The value produced in this study is observed to be close to the findings of previous research while the difference is based on the use of coarse and fine aggregates mixed with cement (concrete) before the coconut fiber was added in previous studies. Meanwhile, only white or chalky soil was added to cement and coconut fiber in this study.

c. The white soil brick with rice husk ash 1-part cement volume (BTPASP1) has an average weight of 1821 grams after 28 days and this is observed to be lighter than BTPASP2 bricks with 2062 grams. This means the addition of 1.5 rice husk ash increased the brick weight by 13.2\%. These results are different from the findings of previous research by Wahyuni et al. (2015) which was lighter after rice huskash was added (Wahyuni, Habsya, and Sunarsih 2015).

d. The bricks with coconut fiber were found to become less-weighted due to the addition of the material as observed with 2208 grams recorded for BTPSSK2 and 2257 grams for BTPSSK1 bricks. This, therefore, means adding 1.5 coconut husk reduces the weight by $2.2 \%$. This is similar to a previous study by Fandy et al. (2013). These results are presented in table 6 and figure 12 .

Table 6. Weight and average compressive strength of experimental results

\begin{tabular}{llll}
\hline No & Brick code & $\begin{array}{l}\text { Weight } \\
\text { (gram) }\end{array}$ & $\begin{array}{l}\text { Compressive } \\
\text { strength } \\
\text { (kg/cm² }\end{array}$ \\
\hline 1 & BTPASP1 & 1821 & 53,5 \\
\hline 2 & BTPASP2 & 2062 & 95,5 \\
\hline 3 & BTPSSK1 & 2257 & 136,5 \\
\hline 4 & BTPSSK2 & 2208 & 96 \\
\hline
\end{tabular}




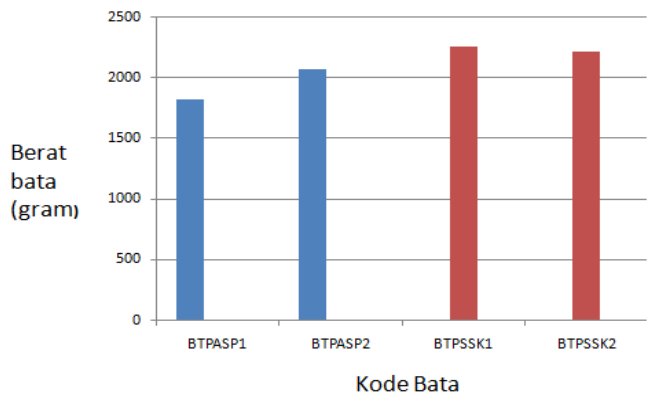

Figure 12. Average weight diagram of experimental brick (Brick weight, brick code)

e. The compressive strength results showed the 1-part addition of rice husk ash to the white soil brick dough has the ability to produce an average brick compressive strength of 53.5 $\mathrm{kg} / \mathrm{cm}^{2}$ on BTPASP1 bricks while the addition of 1.5 parts to BTPASP2 bricks increased the value by an average of $95.5 \mathrm{~kg} / \mathrm{cm}^{2}$ or $78.5 \%$. The results also showed the maximum compressive strength was found in 1 cement: 1.5 rice husks: 7 white soil volume ratio and this was found to be the same as previous studies where the addition of rice husk ash increased the compressive strength of bricks (Abdian and Herbudiman 2010).

f. In coconut fiber bricks, each addition of 1-part coconut fiber to the white soil dough, produced an average compressive strength of $136.5 \mathrm{~kg} / \mathrm{cm}^{2}$ while the addition of 1.5 yielded $96 \mathrm{~kg} / \mathrm{cm}^{2}$ which is a $42.2 \%$ decrease. Therefore, the maximum fiber used is 1-part of the overall ratio of the mixture which is 1 cement: 1 coconut fiber: 7 white soil as shown in figure 13 .

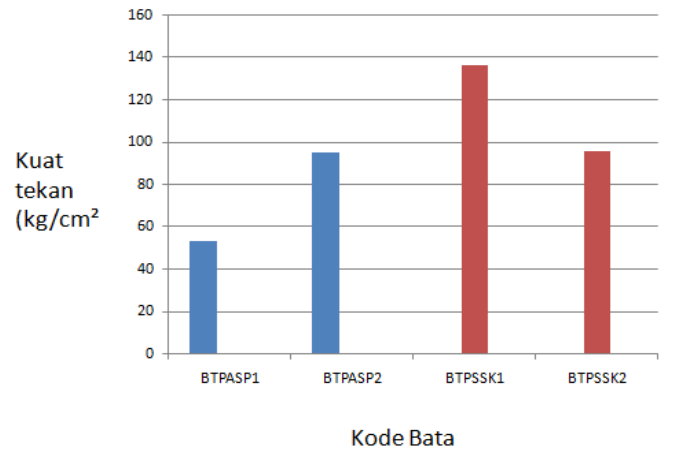

Figure 13. Compressive strength diagram of experimental bricks (Compressive strength, brick code)

\section{Analysis of brick usage based on compressive strength requirements}

According to SNI 03-0349-1989, bricks with rice husk ash (BTPASP) and coconut fiber (BTPSSK) are categorized as quality I brick with a compressive strength requirement of $90 \mathrm{~kg} / \mathrm{cm}^{2}$, and quality II with $65 \mathrm{~kg} / \mathrm{cm}^{2}$ as shown in table 7 .

Table 7. Compressive strength based on the physical requirements of SNI 03-0349-1989 concrete bricks

\begin{tabular}{cccc}
\hline No & Quality & $\begin{array}{c}\text { Requirements for } \\
\text { compressive strength } \\
\left(\mathbf{k g} / \mathbf{c m}^{2}\right)\end{array}$ & Brick \\
\hline 1 & I & 90 & $\begin{array}{c}\text { BTPASP2, } \\
\text { BTPSSK1 } \\
\text { BTPSSK2 }\end{array}$ \\
\hline 2 & II & 65 & $\begin{array}{c}\text { BTPASP1 } \\
\left(53,5 \mathrm{~kg} / \mathrm{cm}^{2}\right)\end{array}$ \\
\hline 3 & III & 35 & \\
\hline 4 & IV & 21 & \\
\hline
\end{tabular}

Analysis of brick usage based on compressive strength requirements of conblock

Table 8 shows the analysis of brick usage based on the conblocks compressive strength requirements.

Table 8. Requirements for compressive strength of conblock (Frick and Purwanto 1997)

\begin{tabular}{llll}
\hline $\begin{array}{l}\text { Construction } \\
\text { Type }\end{array}$ & $\begin{array}{l}\text { Minimum } \\
\text { compressive } \\
\text { strength } \\
\text { requirements }\end{array}$ & Used brick \\
\hline 1 & $\begin{array}{l}\text { Overburdened and } \\
\text { unprotected } \\
\text { constructions }\end{array}$ & $66,30 \mathrm{~kg} / \mathrm{cm}^{2}$ & $\begin{array}{l}\text { BTPASP2 } \\
\text { BTPSSK1 } \\
\text { BTPSSK2 }\end{array}$ \\
\hline 2 & $\begin{array}{l}\text { Loaded and } \\
\text { protected } \\
\text { construction }\end{array}$ & $45,90 \mathrm{~kg} / \mathrm{cm}^{2}$ & $\begin{array}{l}\text { BTPASP1, } \\
\text { all brick }\end{array}$ \\
\hline 3 & $\begin{array}{l}\text { Unencumbered } \\
\text { and unprotected } \\
\text { construction }\end{array}$ & $30,60 \mathrm{~kg} / \mathrm{cm}^{2}$ & all brick \\
\hline 4 & $\begin{array}{l}\text { Unencumbered } \\
\text { and protected } \\
\text { construction. }\end{array}$ & $17,34 \mathrm{~kg} / \mathrm{cm}^{2}$ & all brick \\
\hline
\end{tabular}

The experimental bricks including BTPASP2, BTPSSK1, and BTPSSK2 are observed to be applicable in loaded and unprotected constructions while BTPASP1 are useable in burdened and protected construction and the remaining construction types are allowed to use all types of bricks. 


\section{Conclusion}

The discussion and analysis of the results showed (1) the addition of rice husk ash or coconut fiber increased the compressive strength of white soil bricks and meets the SNI 03-0349-1989 Concrete Bricks Requirements with 3 out of the 4 variants including BTPASP2, BTPSSK1, and BTPSSK2 included in the first quality brick, (2) the addition of coconut fiber reduces the brick weight with 1part coconut fiber added observed to produce a brick weight of 2257 grams while 1.5-part had 2208 grams to indicate a $2.2 \%$ reduction in weight, (3) the addition of rice husk ash actually increased the brick weight as observed from the 1821 grams for 1-part of ASP compared to 2062 for the 1.5-part which indicates $13.2 \%$ addition to the weight, and (4) the compressive strength of the brick meets the requirements for use in loaded and unprotected constructions by being at least $6.5 \mathrm{~N} / \mathrm{mm}^{2}$ or $66.30 \mathrm{~kg} / \mathrm{cm}^{2}$.

This, therefore, implies the three variations including BTPASP2, BTPSSK1, and BTPSSK2 with compressive strength above $90 \mathrm{~kg} / \mathrm{cm}^{2}$ are applicable in loaded and unprotected constructions, BTPASP1 are suitable for burdened but protected construction while others such as being unencumbered, protected or unprotected are allowed to use all the types of bricks.

This research has a novelty value due to the fact that no one has used white soil material to make solid brick with the addition of rice huskash or coconut fiber.

\section{References}

Abdian, Ramanuddin M., and Bernardinus Herbudiman. 2010. 'Pengaruh Kehalusan Dan Kadar Abu Sekam Padi Pada Kekuatan Beton Dengan Kuat Tekan $50 \mathrm{MPa}$. In Konferensi Nasional Teknik Sipil 4 (KoNTekS 4), 181-88. Sanur, Bali: Universitas Udayana. https://docplayer.info/44921769-Pengaruhkehalus an-dan-kadar-abu-s ekam-padi-padakekuatan-beton-dengan-kuat-tekan-50mpa.html.

Arman. 2016. 'Studi Eksperimental Pengaruh Penambahan Serat Sabut Kelapa Terhadap Kuat Tarik Beton Normal Fc' 18 MPa'. Jurnal Momentum $18 \quad$ (2): $\quad$ 6-10. https ://doi.org/10.21063/JM.2016. V18.2.610.

Bebhe, Kristiana. 2017. 'Eksperimen Bata Tanah Liat Yang Distabilisasi Dengan Semen Kupang'. Jurnal Ilmiah Realtech 13 (1).

—. 2018. 'Pengaruh Penembahan Kapur Pada Peningkatan Kuat Tekan Bata Tanah Liat Kapur Press'. In RITEKRA VIII: Rekayasa Dan Inovasi IPTEKS Dalam Membangun Negara Maritim. Makassar: Fakultas Teknik, Universitas Katolik Atma Jaya Jakarta. https://docplayer.info/134270813-Prosidingseminar-nasional-riset-dan-teknologiterapan-ke-8-ritektra-viii-2018.html.

Budiman, and James Williams Tiranda Patanduk. 2018. 'Penambahan Serat yang Optimal Terhadap Kuat Tekan Beton pada Beton Normal'. Jurnal Inovtek Polbeng 8 (2): 16874. https://doi.org/10.35314/ip.v8i2.477.

Coniwanti, Pamilia, Rasmiah Srikndhy, and Apriliyanni. 2008. 'Pengaruh Proses Pengeringan, Normalitas $\mathrm{HCl}$, dan Temperatur Pembakaran pada Pembuatan Silika dari Sekam Padi'. Jurnal Teknik Kimia $15 \quad$ (1): 5-11. http://jtk.unsri.ac.id/index.php/jtk/article/vie w/42.

Elhusna, and Jefri Suwandi. 2012. 'Peningkatan Kuat Tarik Beton Akibat Penambahan Serat Sabut Kelapa'. Inersia 4 (1): 17-23. https://ejournal.unib.ac.id/index.php/inersiaju rnal/article/view/6708.

Fandy, Anita, and Handoko. 2013. 'Pengaruh Pemanfaatan Serat Sabut Kelapa dengan Perlakuan Alkali Terhadap Kuat Tekan dan Kuat Tarik Beton'. Jurnal Dimensi Pratama Teknik Sipil 2 (2): $1-8$. http://publication.petra.ac.id/index.php/teknik -sipil/article/view/1192/1079.

Frick, Heinz, and L. M. F. Purwanto. 1997. Sistem Bentuk Struktur Bangunan: Dasar-Dasar Konstruksi Dalam Arsitektur. Yogyakarta: Kanisius.

Is mail, Muhammad Shoaib, and A.M. Waliuddin. 1996. 'Effect of Rice Husk Ash on High Strength Concrete'. Construction and Building Materials 10 (7): 521-26. https://doi.org/10.1016/0950-0618(96)000104.

Mulyono, Tri. 2004. Teknologi Beton. 1st ed. Yogyakarta: Andi.

Sahrudin, and Nadia. 2016. 'Pengaruh Penambahan Serat Sabut Kelapa Terhadap 
Kuat Tekan'. JURNAL KONSTRUKSIA (eJournal) $\quad 7 \quad$ (2): $13-20$. https ://jurnal.umj.ac.id/index.php/konstruksia /article/view/998/910.

Susilowati, Anni, Krisno Arif Simanullang, and Lauditta Aprilia. 2016. 'Bata Beton (Paving Block) Geopolimer Dengan Varias i Konsentrasi Serat Sabut Kelapa'. Jurnal Poli Teknologi 15 https://doi.org/10.32722/pt.v15i1.786.

Wahyuni, Ari Sri, Chundakus Habsya, and Ernawati Sri Sunarsih. 2015. 'Pengaruh
Pemanfaatan Abu Sekam Padi Pada Bata Beton Ringan Foam Terhadap Kuat Tekan, Berat Jenis, Dan Daya Serap Air Sebagai Suplemen Bahan Ajar Mata Kulaih Teknologi Beton (Pada Mahasiswa Semester III PTB FKIP UNS)'. Indonesian Journal Of Civil Engineering Education 1 (1): 1-13. https://doi.org/10.20961/ijcee.v2i2.17930.

Zulfikar. 2014. 'Uji Kuat Tekan Bata Dari Abu Sekam'. Universitas Syiah Kuala Darussalam, Banda Aceh. 
ARTEKS : Jurnal Teknik Arsitektur, Volume 6 Issue 1, April 2021

pISSN2541-0598; eISSN2541-1217 